\title{
Formation of InAs quantum dot arrays on GaAs (100) by self- organized anisotropic strain engineering of a (In,Ga)As superlattice template
}

\author{
Citation for published version (APA): \\ Mano, T., Nötzel, R., Hamhuis, G. J., Eijkemans, T. J., \& Wolter, J. H. (2002). Formation of InAs quantum dot \\ arrays on $\mathrm{GaAs}(100)$ by self-organized anisotropic strain engineering of a (In, Ga)As superlattice template. \\ Applied Physics Letters, 81(9), 1705-1707. https://doi.org/10.1063/1.1503872
}

DOI:

10.1063/1.1503872

Document status and date:

Published: 01/01/2002

Document Version:

Publisher's PDF, also known as Version of Record (includes final page, issue and volume numbers)

\section{Please check the document version of this publication:}

- A submitted manuscript is the version of the article upon submission and before peer-review. There can be important differences between the submitted version and the official published version of record. People interested in the research are advised to contact the author for the final version of the publication, or visit the DOI to the publisher's website.

- The final author version and the galley proof are versions of the publication after peer review.

- The final published version features the final layout of the paper including the volume, issue and page numbers.

Link to publication

\footnotetext{
General rights

- You may freely distribute the URL identifying the publication in the public portal. follow below link for the End User Agreement:

www.tue.nl/taverne

\section{Take down policy}

If you believe that this document breaches copyright please contact us at:

openaccess@tue.nl

providing details and we will investigate your claim.
}

Copyright and moral rights for the publications made accessible in the public portal are retained by the authors and/or other copyright owners and it is a condition of accessing publications that users recognise and abide by the legal requirements associated with these rights.

- Users may download and print one copy of any publication from the public portal for the purpose of private study or research.

- You may not further distribute the material or use it for any profit-making activity or commercial gain

If the publication is distributed under the terms of Article 25fa of the Dutch Copyright Act, indicated by the "Taverne" license above, please 


\title{
Formation of InAs quantum dot arrays on GaAs (100) by self-organized anisotropic strain engineering of a (In,Ga)As superlattice template
}

\author{
T. Mano, ${ }^{\text {a) }}$ R. Nötzel, G. J. Hamhuis, T. J. Eijkemans, and J. H. Wolter \\ COBRA Inter-University Research Institute, Eindhoven University of Technology, P.O. Box 513, \\ 5600MB Eindhoven, The Netherlands
}

(Received 25 March 2002; accepted for publication 8 July 2002)

\begin{abstract}
We demonstrate the formation of well-defined InAs quantum dot (QD) arrays by self-organized engineering of anisotropic strain in a (In,Ga)As/GaAs superlattice (SL). Due to the accumulation and improvement of the uniformity of the strain-field modulation along [011], formation of InAs QD arrays along [0-11] with $140 \mathrm{~nm}$ lateral periodicity is clearly observed on the SL template when the number of SL periods is larger than ten. By enhancing the In adatom surface migration length at low growth rates, clear arrays of single InAs QDs are obtained. The QD arrays exhibit strong photoluminescence efficiency that is not reduced compared to that from InAs QD layers on GaAs. Hence, ordering by self-organized anisotropic strain engineering maintains the high structural quality of InAs QDs. C 2002 American Institute of Physics. [DOI: 10.1063/1.1503872]
\end{abstract}

The fabrication of quantum dots (QDs) by selfassembled growth methods has been intensively investigated in the last decade for basic physics and device applications. ${ }^{1,2}$ However, in spite of the development of various growth methods, ${ }^{3-5}$ many hurdles still remain which have to be overcome for the realization of QD devices with the predicted properties. ${ }^{1,2}$ QDs formed in the StranskiKrastanov growth mode, which has been most widely utilized on (100) surfaces, are usually arranged randomly. ${ }^{4}$ For many applications, however, it is highly desirable to control the position of QDs in well-ordered arrays. To achieve this goal, many groups have investigated the formation of QD arrays using multilayer high stepped vicinal substrates or strained layer growth on patterned substrates. ${ }^{6-10}$ These approaches, however, often suffer from a degradation of the structural perfection and optical quality of the QD arrays, which is attributed to step edge roughness or pattern irregularities on the dot-diameter and dot-to-dot distance length scales, introducing defects and size fluctuations in the QD arrays.

To overcome these problems, we report a method for InAs QD ordering on planar singular GaAs (100), which is based on the self-organized engineering of anisotropic strain in a (In,Ga)As/GaAs superlattice (SL) template. During the growth of a (In,Ga)As/GaAs SL at elevated temperatures, elongated (In,Ga)As QDs develop into very uniform and long quantum wire arrays along [0-11] with well-defined lateral periodicity. ${ }^{11,12}$ Utilizing this self-organized (In,Ga)As quantum wire array as a template for InAs QD growth, we have realized single and multiple InAs QD arrays with 140 $\mathrm{nm}$ lateral periodicity. The template effect is highlighted by the distinct dependence of the QD ordering on the number of SL periods. The photoluminescence (PL) efficiency of the QD arrays is not reduced compared to that of InAs QDs grown directly on GaAs showing the high structural and optical quality of our QD arrays.

The samples were grown on GaAs (100) substrates with

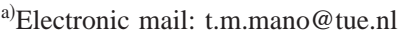

a miscut smaller than $0.05^{\circ}$ by conventional solid-source molecular beam epitaxy (MBE). After growth of a $200 \mathrm{~nm}$ thick GaAs buffer layer at $580^{\circ} \mathrm{C}$, the samples were cooled down to $540^{\circ} \mathrm{C}$ for growth of $(\mathrm{In}, \mathrm{Ga})$ As. After each $(\mathrm{In}, \mathrm{Ga}) \mathrm{As}$ layer, capped with $0.9 \mathrm{~nm} \mathrm{GaAs}$, of the $\mathrm{In}_{0.36} \mathrm{Ga}_{0.64} \mathrm{As} / \mathrm{GaAs}(2.6 \mathrm{~nm} / 16 \mathrm{~nm}) \mathrm{SL}$, the samples were annealed at $580^{\circ} \mathrm{C}$ for 2 min. before $\mathrm{GaAs}$ growth was completed. ${ }^{11}$ The number of SL periods was varied between 1 and 15 in different samples. On top of the last GaAs layer of the SL, 1.5-2.1 monolayers (ML) InAs were grown at $480^{\circ} \mathrm{C}$ for QD formation. For PL studies, these InAs QD layers were capped by $100 \mathrm{~nm}$ GaAs. The growth rates of GaAs, InAs, and $\mathrm{In}_{0.36} \mathrm{Ga}_{0.64}$ As were $0.067 \mathrm{~nm} / \mathrm{s}, 0.037 \mathrm{~nm} / \mathrm{s}$ or $0.0007 \mathrm{~nm} / \mathrm{s}$, and $0.104 \mathrm{~nm} / \mathrm{s}$, which were calibrated by high-resolution x-ray diffraction (XRD) measurements of $(\mathrm{In}, \mathrm{Ga}) \mathrm{As} / \mathrm{GaAs} \mathrm{SL}$ structures grown at $480^{\circ} \mathrm{C}$. The structural properties of the uncapped InAs QD layers were characterized by atomic force microscopy (AFM) in air. For the PL measurements, the $512 \mathrm{~nm}$ line of a Nd-YAG laser was used for excitation with an excitation power density of $0.2 \mathrm{~W} / \mathrm{cm}^{2}$. The PL was dispersed by a single monochromator and recorded by a cooled (In,Ga)As charge-coupled device.

Figures 1(a)-(d) show the AFM images of the QDs formed by $2.1 \mathrm{ML}$ InAs grown at a rate of $0.037 \mathrm{~nm} / \mathrm{s}$ on the (In,Ga)As/GaAs SL template with the number of SL periods of [Fig. 1(a)] 1, [Fig. 1(b)] 5, [Fig. 1(c)] 10, and [Fig. 1(d)] 15 , respectively. For comparison, the AFM image of InAs QDs grown directly on the GaAs buffer layer is shown in Fig. 1(e). While on the GaAs buffer layer the InAs QDs are randomly arranged, a distinct tendency for QD ordering is observed on the SL when the number of SL periods is increased from 1 to 15. The large size QDs observed in Fig. 1 are due to coalescence of few small QDs. For one period [Fig. 1(a)], QD ordering is hardly observed, indicating large disorder or incomplete wire formation of the template. When the number of periods is increased to 5 [Fig. 1(b)], a weak modulation of the island density towards QD ordering appears. The selectivity of QD formation, however, is poor 

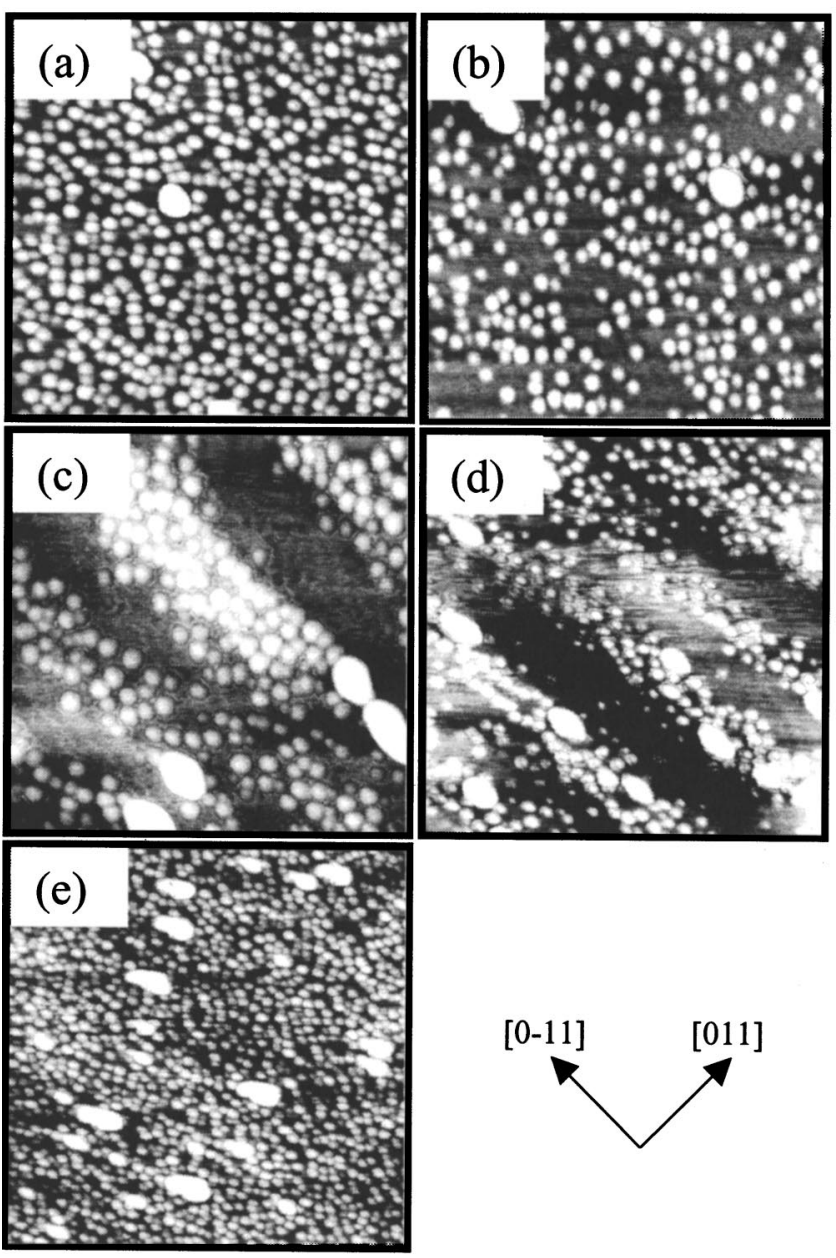

FIG. 1. (a), (b), (c), and (d) are AFM images of 2.1 ML InAs QDs grown on $1,5,10$, and 15 periods SL template with a growth rate of $0.037 \mathrm{~nm} / \mathrm{s}$. (e) is the AFM image of 2.1 ML InAs QDs grown on GaAs (100) buffer layer. The scan field is $500 \mathrm{~nm} \times 500 \mathrm{~nm}$ and the black-to-white height contrast is $7 \mathrm{~nm}$ for all images.

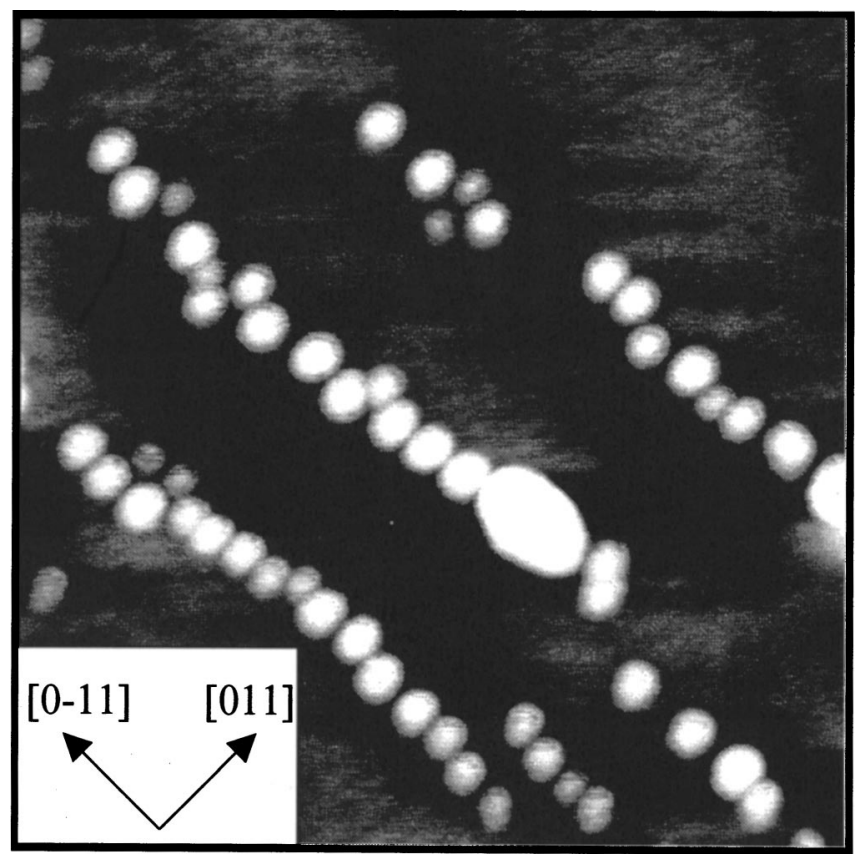

FIG. 2. AFM image of 1.5 ML InAs QDs grown on 15 periods SL template with a growth rate of $0.0007 \mathrm{~nm} / \mathrm{s}$. The scan field is $500 \mathrm{~nm} \times 500 \mathrm{~nm}$ and the black-to-white height contrast is $15 \mathrm{~nm}$. Downloaded 17 Mar 2009 to 131.155.108.71. Redistribution subject to AIP license or copyright; see http://apl.aip.org/apl/copyright.jsp

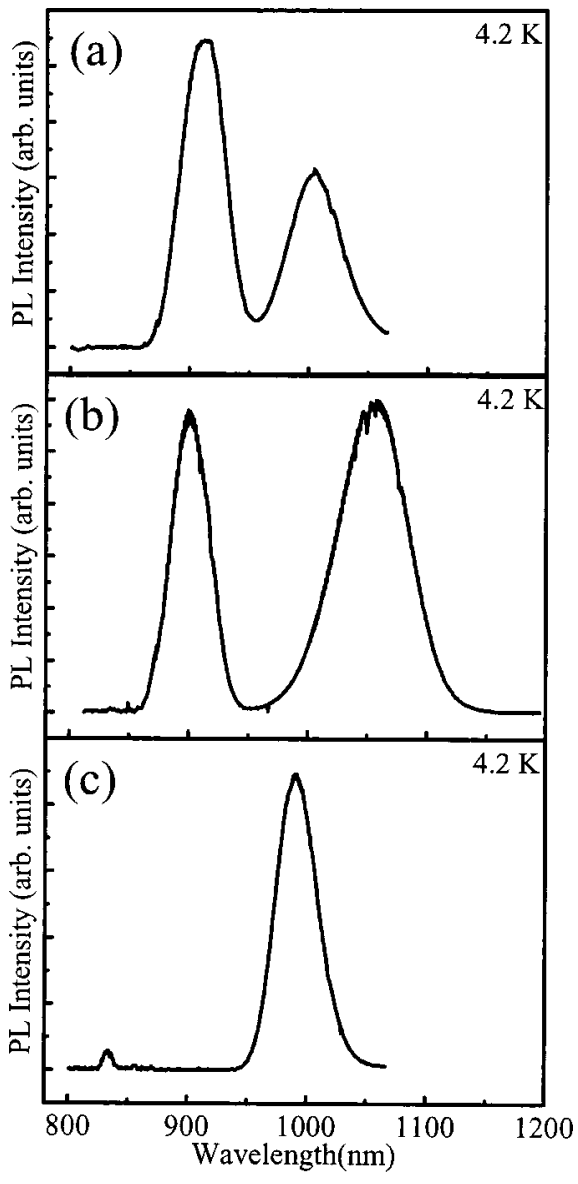

FIG. 3. (a) and (b) are PL spectra taken at $4.2 \mathrm{~K}$ from 2.1 ML InAs QDs $(0.037 \mathrm{~nm} / \mathrm{s})$ and $1.5 \mathrm{ML}$ InAs QDs $(0.0007 \mathrm{~nm} / \mathrm{s})$ grown on 15 periods SL template. (c) shows the PL spectrum of $2.1 \mathrm{ML}$ InAs QDs $(0.037 \mathrm{~nm} / \mathrm{s})$ grown on GaAs (100) buffer layer.

with many dots located randomly. On the other hand, for 10 and 15 SL periods [Figs. 1(c) and 1(d)], very clear ordering in arrays of multiple QDs along [0-11] is observed. The length of the arrays easily exceeds $3 \mu \mathrm{m}$ with a lateral periodicity of $140 \mathrm{~nm}$ along [011]. This periodicity is consistent with the lateral periodicity of the (In, Ga)As wires, measured by $\mathrm{XRD},{ }^{13}$ thus additionally confirming the template effect.

The improved InAs QD ordering with increasing number of (In, Ga)As/GaAs SL periods is attributed to the improved uniformity of the wires and related uniformity and accumulation of the strain field on the GaAs surface. This generates a well-defined lateral strain-field modulation perpendicular to the wires with sufficiently deep minima above the wires providing the preferred locations for QD nucleation. ${ }^{14}$ It should be noted that the GaAs surface of the SL exhibits an anisotropic mound structure with $2-5 \mathrm{~nm}$ height, which is enhanced due to the strain accumulation of the underlying wires, though the reflection high-energy electron diffraction patterns are streaky. The length of these mounds along [0-11], which are composed of (100) terraces and ML high steps, is between $500 \mathrm{~nm}$ and about $1 \mu \mathrm{m}$, determined by AFM. This is considerably shorter than the length of the QD arrays, underlining the dominance of the uniform strain field to be in origin of the QD ordering.

Formation of single QD arrays is achieved by reducing the InAs coverage and, most important, enhancing the In adatom migration length at low growth rates. ${ }^{15}$ QD nucle- 
ation is then expected only at the most favored locations, which are assumed above the centers of the wires. Figure 2 shows the AFM image of the QDs formed by 1.5 ML InAs grown at a rate of $0.0007 \mathrm{~nm} / \mathrm{s}$ on the 15 periods SL template at $480^{\circ} \mathrm{C}$. The formation of single InAs QD arrays with an average lateral spacing of $140 \mathrm{~nm}$ and QD distance of only a few nanometers is clearly observed on the SL template.

The PL spectra of capped 2.1 ML InAs QDs (growth rate: $0.037 \mathrm{~nm} / \mathrm{s}$ ) and $1.5 \mathrm{ML}$ InAs QDs (growth rate: 0.0007 $\mathrm{nm} / \mathrm{s}$ ) on the 15 periods SL template are shown in Figs. 3(a) and 3(b), respectively. For comparison, the PL spectrum of capped InAs QDs grown directly on the GaAs buffer layer at the rate of $0.037 \mathrm{~nm} / \mathrm{s}$ is shown in Fig. 3(c). The QD arrays on the SL template reveal strong PL emission centered [Fig. 3(a)] at $1005 \mathrm{~nm}(1.23 \mathrm{eV})$ and [Fig. 3(b)] at $1057 \mathrm{~nm}(1.17$ $\mathrm{eV})$. The line at $911 \mathrm{~nm}(1.36 \mathrm{eV})$ stems from the SL template. Most important, the PL efficiency of the QD arrays on the SL template is not degraded compared to that from the reference sample with comparable full width at half maximum. We relate this high structural and optical quality of the QD arrays to the smoothness of the strain-field modulation on the dot-diameter and dot-to-dot distance length scales which is an advantage of our method based on self-organized strain engineering for QD ordering.

In conclusion, well-defined InAs QD arrays along [0-11] were formed by MBE on planar GaAs (100) by selforganized anisotropic strain engineering of a (In,Ga)As/ GaAs SL template. The template effect was demonstrated by the dependence of the QD ordering on the number of SL periods. For low growth rates, single QD arrays were real- ized. The separation between the arrays along [011] is 140 $\mathrm{nm}$ while the QD distance along [0-11] is only a few nanometers. The QD arrays exhibit strong PL emission indicating that ordering by self-organized anisotropic strain engineering maintains the high structural quality of InAs QDs. Hence, this technique is highly promising for QD ordering in welldefined arrays of high quality.

${ }^{1}$ Y. Arakawa and H. Sakaki, Appl. Phys. Lett. 40, 939 (1982).

${ }^{2}$ H. Sakaki, Jpn. J. Appl. Phys., Part 1 19, 735 (1980).

${ }^{3}$ N. Koguchi, S. Takahashi, and T. Chikyow, J. Cryst. Growth 101, 688 (1991).

${ }^{4}$ D. Leonard, M. Krishnamurthy, C. M. Reaves, S. P. Denbaars, and P. M. Petroff, Appl. Phys. Lett. 63, 3203 (1993).

${ }^{5}$ R. Nötzel, J. Temmyo, and T. Tamamura, Nature (London) 369, 131 (1994).

${ }^{6}$ M. Kitamura, M. Nishioka, J. Oshinowo, and Y. Arakawa, Appl. Phys. Lett. 66, 3663 (1995).

${ }^{7}$ D. S. L. Mui, D. Leonard, L. A. Coldren, and P. M. Petroff, Appl. Phys. Lett. 66, 1620 (1995).

${ }^{8}$ A. Konkar, A. Madhukar, and P. Chen, Appl. Phys. Lett. 72, 220 (1998).

${ }^{9}$ W. Seifert, N. Carlsson, A. Petersson, L.-E. Wernersson, and L. Samuelson, Appl. Phys. Lett. 68, 1684 (1996).

${ }^{10}$ H. Lee, J. A. Johnson, J. S. Speck, and P. M. Petroff, J. Vac. Sci. Technol. B 18, 2193 (2000).

${ }^{11}$ W. Ma, R. Nötzel, A. Trampert, M. Ramsteiner, H. Zhu, H.-P. Schönherr, and K. H. Ploog, Appl. Phys. Lett. 78, 1297 (2001).

${ }^{12}$ W. Ma, R. Nötzel, H.-P. Schönherr, and K. H. Ploog, Appl. Phys. Lett. 79, 4219 (2001).

${ }^{13}$ From XRD recorded in the vicinity of the glancing exit (311) reflection, the wire periodicity along [011] is $160 \mathrm{~nm}$.

${ }^{14}$ Q. Xie, A. Madhukar, P. Chen, and N. P. Kobayashi, Phys. Rev. Lett. 75, 2542 (1995)

${ }^{15}$ P. B. Joyce, T. J. Krzyzewski, G. R. Bell, T. S. Jones, S. Malik, D. Childs, and R. Murray, J. Cryst. Growth 227, 1000 (2001). 